Fakultas Hukum Universitas Lancang Kuning, Jalan Yos Sudarso KM 8 Rumbai Pekanbaru, Riau, Kode Pos 28266. Telp: (+62761)-51877

E-mail: jurnal.respublica@ac.id

Website: https://journal.unilak.ac.id/index.php/Respublica

\title{
Kewajiban Uji Berkala Kendaraan Bus di Dinas Perhubungan Kabupaten Kampar
}

\author{
Arben $^{\mathrm{a}}$ \\ ${ }^{a}$ Dinas Perhubungan, Indonesia, Email: arben@gmail.com
}

\section{ArticleInfo}

\section{Article History:}

Diterima : 11-11-2020

Direvisi : 20-03-2021

Disetujui : 10-02-2021

Diterbitkan : 28-05-2021

\section{Keywords:}

Keyword 1 : Obligation

Keyword 2 : Periodic Test

Keyword 3 : Bus Vehicle

\section{Informasi Artikel}

\section{Histori Artikel:}

Diterima : 11-11-2020

Direvisi : 20-03-2021

Disetujui : $10-02-2021$

Diterbitkan : 28-05-2021

\section{Kata Kunci:}

Kata Kunci 1 : Kewajiban

Kata Kunci 2 : Uji Berkala

Kata Kunci 3 : Kendaraan Bus

\begin{abstract}
How is the implementation of the obligation to periodically test bus vehicles based on Law number 22 of 2009 concerning road traffic and transportation at the Kampar district transportation office. How are the obstacles and efforts to carry out periodic testing of bus vehicles based on Law number 22 of 2009 concerning road traffic and transportation at the Kampar district transportation office. this type of research is a type of sociological legal research. the obligation to periodically test bus vehicles based on law number 22 of 2009 concerning road traffic and transportation in Kampar district has not been able to be carried out properly. The obstacle in this research is that due to geographical factors, economic factors and the low level of public awareness to carry out periodic testing. The efforts made by the Kampar Regency Transportation Service are influenced by geographical factors. economic factors, the transportation agency, the owner's awareness factor.
\end{abstract}

\begin{abstract}
Abstrak
Bagaimanakah pelaksanaan kewajiban uji berkala kendaraan bus berdasarkan Undang-Undang nomor 22 Tahun 2009 tentang lalu lintas dan angkutan jalan di dinas perhubungan kabupaten Kampar. bagaimanakah hambatan dan upaya kewajiban uji berkala kendaraan bus berdasarkan Undang-Undang nomor 22 tahun 2009 tentang lalu lintas dan angkutan jalan di dinas perhubungan kabupaten Kampar. jenis penelitian ini adalah jenis penelitian hukum sosiologis. kewajiban uji berkala kendaraan bus berdasarkan undang-undang nomor 22 tahun 2009 tentang lalu lintas dan angkutan jalan di kabupaten Kampar belum dapat terlaksana sebagaimana mestinya. hambatan dalam penelitian ini bahwa dikarenakan faktor geografis, faktor ekonomi dan faktor rendahnya kesadaran masyarakat untuk melakukan pengujian berkala. upaya yang dilakukan dinas perhubungan kabupaten kampar adalah di pengaruhi oleh faktor geografis,. faktor ekonomi, dinas perhubungan faktor kesadaran pemilik.
\end{abstract}

\section{PENDAHULUAN}

Terselenggaranya pengangkutan adalah konsekuensi logis dari adanya hubungan timbal balik dalam hal ini antara pengangkut dengan penumpang. Dalam proses pengangkutan orang, kelayakan kendaraan angkutan orang adalah salah satu ketentuan utama yang sangat 
penting untuk diperhatikan dan dilaksanakan oleh pihak penyelenggara pengangkutan orang. Hal ini dikarenakan dalam proses pengangkutan orang di jalan raya. ${ }^{1}$

Kendaraan angkutan orang adalah modal transportasi utama dalam pelaksanaan pengangkutan sewa. Sedangkan kelayakan kendaraan bermotor atau angkutan orang yang dioperasikan di jalan raya telah ditentukan oleh Undang-undang Nomor 22 Tahun 2009 tentang lalu lintas dan pengangkutan jalan. Menurut ketentuan Undang-undang Nomor 22 Tahun 2009 tentang lalu lintas dan pengangkutan jalan, setiap kendaraan bermotor yang dioperasikan di jalan raya harus memenuhi persyaratan teknis dan layak jalan. ${ }^{2}$

Konsep pengujian berkala kendaraan bermotor merupakan konsep yang baik untuk mengurangi resiko kecelakaan dan pencemaran udara akibat beroperasinya kendaraan bermotor dan seharusnya pengujian berkala diberlakukan untuk semua kendaraan bermotor, karena semua kendaraan bermotorberdampak terhadap kecelakaan dan polusi udara. Hal tersebut sejalan dengan amanat Undang-undang Nomor 22 Tahun 2009 tentang Lalu Lintas dan Angkutan Jalan Pasal 53 menyebutkan bahwa pengujian berkala diwajibkan untuk mobil penumpang, umum, mobil bus, mobil barang, kereta gandengan, dan kereta tempelan yang dioperasikan di jalan. ${ }^{3}$

Pelaksaanan uji berkala kendaraan bermotor ini dapat dijadikan salah satu unsur kekuatan penyeimbang dampak negatif yang dapat ditimbulkan oleh kemajuan teknologi kendaraan bermotor. Dalam pelaksanaan uji berkala ini masih terdapat banyak kendala antara lain ketidaklengkapan alat uji bahkan di beberapa unit pengujian masih menggunakan uji visual atau feeling penguji. Untuk pemeriksaan terhadap persyaratan teknis kendaraan bermotor, persyaratan laik jalan ranmor dan Tanda Lulus Uji Berkala dalam pelaksanaan pembuktiannya diperlukan keahlian dan peralatan khusus. Semua pihak harus mengembalikan esensi uji kendaraan bermotor sebagai instrumen manajemen keselamatan publik dan untuk mewujudkan manajemen keselamatan publik. ${ }^{4}$

Kelayakan laik jalan kendaraan penumpang atau barang yang ada di jalan sudah seharusnya diawasi oleh pemerintah. Pengawasan yang dilakukan tersebut berupa uji berkala. Uji berkala yang dilakukan pemerintah, khususnya kementerian perhubungan, sudah jelas diatur dalam undang-undang nomor 22 tahun 2009 tentang Lalu Lintas dan Angkutan Jalan.

\footnotetext{
${ }^{1}$ Adisasmita, S A. Dasar-dasar Ekonomi Transportasi, (Yogyakarta: Graha Ilmu, 2010), 4.

${ }^{2}$ Salim, A. Manajemen Transportasi. (Jakarta : PT. Raja Grafindo Persada, 1993), 3.

${ }^{3}$ http://www.tribunnews.com/otomotif/2016/06/18/mengenal-aturan-uji-kir-kendaraan-umum-dasar-hukumhingga-sanksi, diakses hari Jumat, Tanggal 14 Desember 2018, Jam: 21.00 wib.

${ }^{4}$ Adisasmita, S A. Transportasi dan Pengembangan Wilayahnya, (Yogyakarta: Graha Ilmu, 2011), 42.
} 
Uji berkala sebagaimana dimaksud, wajib dilakukan untuk mobil penumpang umum, bus, barang, keretagandengan, dan kereta tempelan yang dioperasikan di Jalan. Pengujian berkala tersebut meliputi kegiatan, pemeriksaan dan pengujian fisik, serta pengesahan basil uji dalam persyaratan teknis atau syarat laik jalan. ${ }^{5}$

Pasal 49 ayat 1 Peraturan Pemerintah Nomor 22 Tahun 2009 tentang Kendaraan dan Pengemudi, bahwa setiap kendaraan bermotor jenis mobil bus, mobil barang, kendaraan khusus, kereta gandengan, dan kereta tempelan yang di impor, dibuat dan/atau dirakit di dalam negri dan kereta umum yang akan diopersikan di jalan wajib dilakukan uji berkala dengan masa uji berkala yang berlaku selama 6 (enam) bulan.

Berdasarkan pengamatan penulis dilapangan bahwa masih banyak ditemukan kendaraan bus umum yang tidak melakukan uji persyaratan laik jalan di Dinas Perhubungan kabupaten Kampar. Pelaksanaan pengujian kendaraan bermotor yang seharusnya wajib dilakukan secara berkala tetapi tidak berjalan dengan efektif, karena masih banyak kurangnya kesadaran dari pemilik bus umum untuk tertib terhadap ataran mengenai pengujian syarat laik jalan. Untuk melihat keadaan Uji Berkala kendaraan bus angkutan umum di Dinas Perhubungan Kabupaten Kampar dapat dilihat pada tabel kasus sebagai berikut:

Tabel 1

Data Uji Berkala Kendaraan Bus Umum Tahun 2016-2018

\begin{tabular}{|c|c|c|c|c|}
\hline Tahun & Jumlah PO & $\begin{array}{c}\text { Jumlah Bus } \\
\text { Umum }\end{array}$ & $\begin{array}{c}\text { Melakukan Uji } \\
\text { Berkala }\end{array}$ & $\begin{array}{c}\text { Tidak Melakukan Uji } \\
\text { Berkala }\end{array}$ \\
\hline 2016 & 13 & 208 & 110 & 98 \\
\hline 2017 & 13 & 208 & 92 & 116 \\
\hline 2018 & 13 & 208 & 135 & 73 \\
\hline
\end{tabular}

Berdasarkan data yang penulis kumpulkan dari Dinas Perhubungan Kabupaten Kampar diketahui bahwa jumlah kendaraan bus umum wajib uji pada Tahun 2016 berjumlah 208 kendaraan bus umum, tetapi yang tidak melakukan pengujian syarat laik jalan sebanyak 98 kendaraan bus umum. Sedangkan untuk data pada Tahun 2017 dijelaskan bahwa jumlah kendaraan bus umum wajib uji pada Tahun 2017 berjumlah 208 kendaraan bus umum, tetapi yang tidak melakukan pengujian syarat laik jalan sebanyak 116 kendaraan bus umum. Tahun 2018 dijelaskan bahwa jumlah kendaraan bus umum wajib uji pada Tahun 2018 berjumlah 
208 kendaraan bus umum, tetapi yang tidak melakukan pengujian syarat laik jalan sebanyak 73 kendaraan bus umum.

Guna menanggulangi ketidakseimbangan tersebut, agar tercipta kondisi lalu lintas dan angkutan yang tertib, aman, dan selamat, lancar, dan terkendali khususnya di bidang pengujian berkala kendaraan bermotor, maka aparat pemerintah dan masyarakat harus patuh pada hukum dan ketentuan peraturan perundang-undangan yang berlaku. ${ }^{6}$

Sejalan dengan memngkatnya pertumbuhan penduduk dan semakin berkembangnya teknologi modern, dimungkinkan akan menimbulkan kondisi atau dampak yang kurang baik karena tidak adanya suatu keseimbangan. Guna menanggulangi ketidakseimbangan tersebut, agar tercipta kondisi lalu lintas dan angkutan yang tertib, aman, dan selamat, lancar, dan terkendali khususnya di bidang pengujian berkala, kendaraan bermotor, maka aparat pemerintah dan masyarakat harus patuh pada hukum dan ketentuan peraturan perundangundangan yang berlaku. ${ }^{7}$

Artikel ini akan membahas tentang kewajiban uji berkala kendaraan bus berdasarkan Undang-Undang Nomor 22 Tahun 2009 tentang Lalu Lintas dan Angkutan Jalan di Dinas Perhubungan Kabupaten Kampar. Tujuannya adalah untuk mengetahui hambatan dan upaya apa yang dapat dilakukan oleh Dinas Perhubungan Kabupaten Kampar dalam menerapkan kewajiban uji berkala kendaraan bus di Kabupaten Kampar.

Jenis penelitian ini adalah jenis penelitian hukum sosiologis. Teknik pengumpulan data dengan menggunakan metode Observasi, Wawancara terstruktur, dan Kajian Pustaka. Kemudian data dianalisis secara Kualitatif dan untuk menarik kesimpulan menerapkan metode berpikir Induktif. Data yang akan dipakai dalam penelitian ini adalah data primer, data sekunder, dan data Tertier.

\section{Pelaksanaan Kewajiban Uji Berkala Kendaraan Bus Berdasarkan Undang-Undang Nomor 22 Tahun 2009 Tentang Lalu Lintas dan Angkutan Umum di Dinas Perhubungan Kabupaten Kampar}

Undang-undang Nomor 22 Tahun 2009 tentang Lalu Lintas dan Angkutan Jalan Pasal 53 menyebutkan bahwa pengujian berkala diwajibkan untuk mobil penumpang, umum, mobil bus, mobil barang, kereta gandengan, dan kereta tempelan yang dioperasikan di jalan.

\footnotetext{
${ }^{6}$ Soegijatna Tjakranegara, Hukum Pengangkutan Barang dan Penumpang, (Jakarta: Rineka Cipta, 2007), 98.

${ }^{7}$ Thomas Subroto, Tanya Jawab Undang-Undang Lalu Lintas dan Angkutan, (Semarang: Dahara Prize, 2008), 74.
} 
Peraturan Pemerintah Nomor 55 Tahun 2012 tentang Kendaraan menyebutkan bahwa, kendaraan bermotor khususnya angkutan umum wajib dilakukan pengujian. Hal ini menjadi penting karena dengan pengujian berkala ini erat hubungannya dengan perizinan. Namun kenyataannya di Kabupaten Kampar masih banyak kendaraan bermotor khususnya Bus angkutan umum yang tidak laik jalan atau dengan kata lain tidak memiliki izin beroperasi. Hal ini dibuktikan bahwa masih banyak ditemukan kendaraan bus umum yang tidak melakukan uji persyaratan laik jalan di Dinas Perhubungan kabupaten Kampar. Pelaksanaan pengujian kendaraan bermotor yang seharusnya wajib dilakukan secara berkala tetapi tidak berjalan dengan efektif, karena masih banyak kurangnya kesadaran dari pemilik bus umum untuk tertib terhadap aturan mengenai pengujian syarat laik jalan.

Standar dari uji laik jalan adalah persyaratan minimum, kondisi suatu kendaraan yang harus dipenuhi agar terjaminnnya keselamatan dan mencegah terjadinya pencemaran udara dan kebisingan lingkungan pada waktu dioperasikan di jalan. Sedangkan uji berkala dijelaskan dalam undang-undang nomor 22 Tahun 2009, pasal 53, yaitu : (a) Uji berkala sebagaimana dimaksud dalam Pasal 49 ayat (2) huruf b diwajibkan untuk mobil penumpang umum, mobil bus, mobil barang, kereta gandengan, dan kereta tempelan yang dioperasikan di Jalan. (b) Pengujian berkala sebagaimana dimaksud pada ayat (1) meliputi kegiatan: (1) Pemeriksaan dan pengujian fisik kendaraan bermotor dan (2) Pengesahan hasil uji.

Pasal 49 ayat 1 Peraturan Pemerintah Nomor 22 Tahun 2009 tentang Kendaraan dan Pengemudi, bahwa setiap kendaraan bermotor jenis mobil bus, mobil barang, kendaraan khusus, kereta gandengan, dan kereta tempelan yang di impor, dibuat dan/atau dirakit di dalam negri dan kereta umum yang akan diopersikan di jalan wajib dilakukan uji berkala dengan masa uji berkala yang berlaku selama 6 (enam) bulan. Tetapi apabila dalam pelaksanaannya pemilik kendaraan tidak melakukan uji berkala akan mendapatkan sanksi yang termaktub dalam Pasal 288 ayat (3); Setiap orang yang mengemudikan mobil penumpang umum, mobil bus, mobil barang, kereta gandengan, dan kereta tempelan yang tidak dilengkapi dengan surat keterangan uji berkala dan tanda lulus uji berkala sebagaimana dimaksud dalam Pasal 106 ayat (5) huruf c, dipidana dengan pidana kurungan paling lama 2 (dua) bulan atau denda paling banyak Rp500.000,00 (lima ratus ribu rupiah).

Berdasarkan hasil wawancara dengan Kepala Dinas Kabupaten Kampar menjelaskan tentang standar pelayanan minimum atau (SPM) dalam melakukan pengujian berkala bahwa, masyarakat pemilik kendaraan wajib uji melakukan pendaftaran dengan membawa syarat- 
syarat seperti, kendaraan wajib uji, buku uji, stnk, dan izin trayek (khusus angkutan umum) akan menerima kwitansi pembayaran. Membawa kendaraan yang akan diuji dan menyerahkan bukti pembayaran, lalu akan menerima formulir pemeriksaan kondisi teknis dan nomor urut pemeriksaan. Pemilik melakukan pemeriksaan kendaraan di ruang pengujian, yang meliputi pengujian, lampu, rem, kebisingan, emisi gas buang, dan kelengkapan lainnya. Pemasangan plat uji dan dinyatakan lulus uji. Apabila kendaraan dinyatakan tidak memenuhi syarat pengujian, maka pemilik diharuskan melakukan perbaikan kendaraannya sesuai dengan rekomendasi kerusakan pada formulir pemeriksaan dalam jangka waktu tertentu untuk diperiksa kembali (Pengujian Ulang). Kemudian standar operasional prosedur atau (SOP) Dishub Kabupaten Kampar dalam melakukan pengujian berkala akan menyediakan unit pengujian kendaraan bermotor bagi Kabupaten/Kota yang memiliki populasi kendaraan wajib uji minimal tiga ratusan kendaraan bus umum wajib uji dan melakukan pengujian tiap enam bulan sekali. Setiap kendaraan jenis penumpang umum, barang, bus, kereta gandengan dan tempelan wajib dilakukan pengujian kendaraan bermotor sehingga disebut kendaraan wajib uji. Beberapa tahapan pengujian meliputi pendaftaran uji perdana, dan uji berkala Mangan atau perpanjang masa berlaku. ${ }^{8}$

Selanjutnya dijelaskan bahwa pengujian kendaraan harus didasari oleh kesadaran masyarakat atau pemilik kendaraan dalam mengurus pengujian kendaraan bermotor (KIR) terbilang rendah. Masyarakat masih berpikir gaya lama, seolah-olah ada petugas yang bisa menjemput buku KIR itu. Lalu diperpanjang dengan sendirinya di rumah. Tradisi seperti itu harusnya dihilangkan, karena saat ini pihak Dishub Kabupaten Kampar sudah membuat suatu pelayanan yang jelas dan akuntabel. Namun tentunya pelayanan tersebut tidak akan berjalan jika kenyataannya kendaraan masyarakat tidak pemah diuji. Sedangkan kita memiliki fasilitas alat uji yang lumayan lengkap. Jika betul-betul dimanfaatkan, maka itulah maknanya retribusi. Artinya, dia membayar retribusi langsung mendapatkan layanan pengujian, sehingga, kalau kendaraannya ada kurang ini dan itu, langsung dibawa ke bengkel untuk dibetulkan. Setelah itu diuji kembali. Kalau tidak lolos, maka pemilik kendaraan harus mengulang lagi. Kalau lolos langsung pihak Dishub memberikan buku KIR. Maka dari itu, masyarakat terutama pemilik angkutan bus penumpang dapat sesegera mungkin untuk melakukan uji berkala. Pastikan kendaraannya itu laik uji jalan demi keselamatan penumpang.

\footnotetext{
${ }^{8}$ Hasil wawancara dengan Bapak Mahadi selaku Kepala Dinas Kabupaten Kampar, pada tanggal 8 November 2018, Jam 10.20 Wib di Kantor Dinas Perhubungan Kabupaten Kampar.
} 
Pihaknya tidak akan memungut biaya tambahan karena sudah ada yang menetapkan besaran KIR tersebut. Apabila masyarakat masih melewati disiplin waktu uji berkala ini, maka jangan heran sewaktu-waktu akan dilakukan razia dan akan diterapkan pula sanksi dan dendanya.

Semua kendaraan bermotor sebelum dioperasikan untuk angkutan umum wajib dilakukan pemeriksaaan oleh petugas penguji. Aparat yang berwenang melakukan pengujian adalah mereka yang telah mengikuti pendidikan dan latihan pengujian kendaraan bermotor. Bagi penguji kendaraan bermotor yang melakukan pelanggaran dalam melakukan tugas pengujian akan dikenakan sanksi. Pelanggaran diklasifikasikan menjadi pelanggaran berat, dikenakan sanksi Pencabutan Surat Keputusan Kompetensi, Sertifikat Kompetensi, dan Tanda Kualifikasi Kompetensi Pengujian Kendaraan Bermotor, pelanggaran sedang, dikenakan sanksi skorsing dari tugas menguji sekurang-kurangnya selama 3 (tiga) bulan atau. setinggitingginya 1 (satu) tahun sejak di jatuhkan putusan sanksi dan pelanggaran ringan, dikenakan sanksi peringatan tertulis.

Berdasarkan hasil wawancara dengan Kepala Dinas Kabupaten Kampar menjelaskan bahwa tujuan dari pelaksanaan pengujian kendaraan bermotor adalah untuk menjamin keselamatan pengguna dalam hal ini sopir dan penumpang kendaraan bermotor kemudian mendukung terwujudnya kelestarian lingkungan yang bisa disebabkan oleh penggunaan kendaraan bermotor. Kemudian untuk melaksanakan pelayanan umum kepada masyarakat. Terkait dengan uji berkala kendaraan bermotor perdana atau yang baru pertama kali akan diuji. Untuk melakukan pendaftaran kendaraan bermotor tentunya wajib uji berkala, pemohon mengajukan permohonan kepada unit pelaksana uji berkala kendaraan bermotor dengan dilengkapi persyaratan berupa dokumen salinan/foto copi surat keterangan identititas pemilik kendaraan bermotor, salinan/foto copi surat Tanda Nomor Kendaraan Bermotor (STNK), salinan/foto copi sertifikat Registrasi Uji Tipe (SRUT) dan/atau pengesahan rancang bangun kendaraan bermotor untuk dilaksanakan pengujian pertama kali. Beberapa berkas juga harus diikutsertakan berupa salinan atau fotocoi kartu identitas pemilik, surat tanda nomor kendaraan dan sertifikat registrasi uji tipe yang menyatakan bahwa kendaraan sudah diuji tipe.

Uji tipe terdiri dari uji fisik untuk pemenuhan persyaratan teknis dan laik jalan serta penelitian rancang bangun dan rekayasa kendaraan. Uji tipe dilaksanakan oleh unit pelaksana uji tipe pemerintah. Uji tipe sebagaimana dimaksudkan wajib dilakukan bagi setiap Kendaraan Bermotor, kereta gandengan, dan kereta tempelan, yang diimpor, dibuat dan/atau dirakit di dalam negeri, Berta modifikasi Kendaraan Bermotor yang menyebabkan perubahan 
tipe. Uji tipe sebagaimana dimaksud diatas bahwa pengujian fisik untuk pemenuhan persyaratan teknis dan laik jalan yang dilakukan terhadap landasan Kendaraan Bermotor dan Kendaraan Bermotor dalam keadaan lengkap. Setelah disetujui oleh Kepala Dinas, Pemilik kendaraan akan mendapatkan disposisi yang ditujukan kepada Unit pelaksana teknis Pengujian Kendaraan bermotor untuk dilakukan pengujian. ${ }^{9}$

Dapat diketahui bahwa standar pelayanan minimum dalam melakukan pengujian berkala masyarakat pemilik kendaraan bus umum wajib uji melakukan pendaftaran dengan membawa syarat-syarat seperti, kendaraan wajib uji, buku uji, stnk, dan izin trayek khusus bus angkutan umum. Penguji akan menerima kwitansi pembayaran dan membawa kendaraan yang akan diuji serta menyerahkan bukti pembayaran, lalu akan menerima formulir pemeriksaan kondisi teknis dan nomor unit pemeriksaan Pemilik melakukan pemeriksaan kendaraan di ruang pengujian, yang meliputi pengujian, lampu, rem, kebisingan, emisi gas buang, dan kelengkapan lainnya. Pemasangan plat uji dan dinyatakan lulus uji. Apabila kendaraan dinyatakan tidak memenuhi syarat pengujian, maka pemilik diharuskan melakukan perbaikan kendaraannya sesuai dengan rekomendasi kerusakan pada formulir pemeriksaan dalam jangka waktu tertentu untuk diperiksa kembali. Pelaksanaan pengujian kendaraan Bus umum di Dinas Perhubungan Kabupaten Kampar sudah berjalan sangat optimal. Segala sarana dan prasarananya mengenai fasilitas tempat gedung, perlengkapan bengkel maupun ahli yang ada pada sumber daya manusianya juga memiliki sertifikasi dari pemerintah.

Berdasarkan hasil wawancara dengan Ketua DPRD Kabupaten Kampar terkait dengan pelaksanaan uji berkala kendaraan bus umum di Kabupaten Kampar menjelaskan bahwa pelaksanaan uji kelayakan kendaraan wajib dilakukan secara berkala dan memiliki masa berlaku dalam jangka waktu tertentu. Uji Kelayakan kendaraan angkutan baik angkutan barang maupun orang tentu sangat menjadi perhatian bagi setiap pelaku usaha jasa transportasi, baik jasa transportasi angkutan barang maupun jasa transportasi angkutan orang. Kelayakan jalan pada setiap kendaraan umum akan dilakukan inspeksi rutin oleh pejabat dinas terkait dalam hal ini Dinas Perhubungan atau langsung dari Kementerian Perhubungan, dengan tujuan menekan angka kerusakan, kecelakaan, serta memberikan kenyamanan bagi pengguna jalan maupun pengguna transportasi. Fenomena ketatnya birokrasi dan prosedural dalam pelaksanaan uji kelayakan kendaraan tentu dengan maksud tertentu dan tujuan tertentu

\footnotetext{
${ }^{9}$ Hasil wawancara, dengan Bapak Mahadi selaku Kepala Dinas Kabupaten Kampar, pada tanggal 8 November 2018, Jam 10.20 Wib di Kantor Dinas Perhubungan Kabupaten Kampar.
} 
pula. Hal ini sudah menjadi peraturan yang sudah ditetapkan oleh dinas terkait. Maka dari itu diharapkan para pelaku usaha transportasi mampu menaatinya. Pelaku usaha transportasi dalam menghadapi uji kelayakan kendaraan tentu memiliki pandangan masing-masing dalam menyikapi peraturan standar kelayakan jalan dari armada kendaraan angkutan mereka. Mengenai pelaksanaan uji berkala terhadap kendaraan Bus umum tinggal kembali pada, pemilik atau pelaku usaha yang memiliki kendaraan bus umum tersebut, apakah demi keselamatan pengemudi dan angkutan penumpangnya mau melakukan uji berkala, demi keselamatan orang banyak. $^{10}$

Faktor dasar penyebab pemilik kendaraan tidak mau melakukan uji berkala salah satu di antaranya hanya merupakan kesadaran pemilik kendaraan untuk melakukan uji berkala masih rendah dan masyarakat menganggapnya penerapan sanksi yang sangat ringan dan dendapun kecil. Bagi kendaraan angkutan orang atau barang yang melanggar uji kelaikan bakal dikenakan sanksi tilang. Pemilik bisa mengambil kendaraan jika sudah menunaikan kewajiban melakukan uji kelaikan. Oleh karena itu mengapa pemilik menunda-nunda untuk menguji kendaraannya, hanya karena, malas dan menganggapnya, hanya banyak buang waktu saja, sehingga, peker aan yang lebih penting masih banyak yang harus didahulukan. Padahal, sesuai dengan peraturan, kendaraan wajib diuji kelaikannya, setiap enam bulan sekali demi keselamatan dan kelaikan kendaraan memang benar, tetapi pemilik masih lebih yakin dengan kondisi kendaraan sehingga selalu mengabaikan aturan karena hanya membuang-buang waktu dan uang saja.

Berdasarkan hasil wawancara, dengan Pemilik PO Bus di Kabupaten Kampar terkait dengan pelaksanaan uji berkala kendaraan bus menjelaskan bahwa persayaratan untuk laik jalan, itu salah satunya adalah wajib melakukan pengujian berkala, memang benar. Dalam pelaksanaannya sekiranya harus melakukan uji berkala, karena enam bulan sekali akan dilakukan uji kelaikan kendaraan hal ini dirasakan sangat ribet, yang pertama dengan waktu, dimana kita, harus bekerja dan bahkan terkadang harus keluar kota, untuk kejar target. Belum tentu dalam pelaksanaan uji berkala pada dinas, perhubungan dapat berjalan lancar. Selain menunggu dan mengantri adalagi pengedaannya yang lambat dan kurang profesional sehingga, banyak juga pemilik kendaraan yang melakukan uji berkala masih mengeluh dengan hasil yang sudah dikerjakan pada saat uji berkala. Yang sudah pernah dialami

\footnotetext{
${ }^{10}$ Hasil wawancara dengan Bapak Ahmad Fikri selaku Ketua DPRD Kabupaten Kampar, pada tanggal 14 November 2018, Jam 14.00 Wib di Kantor DPRD Kabupaten Kampar.
} 
sebelumnya bahwa melakukan uji berkala tersebut sampai bisa terjadi tiga atau empat kali harus datang ke Dinas Perhubungan. Karena mekanismenya Dinas Perhubungan tersebut sifatnya hanya memeriksa saja dan apabila ada kekurangan pada kendaraan tersebut harus dibawa bengkel dengan catatan perbaikan sesuai dengan rekomendasi Dinas Perhubungan. setelah kembali dari bengkel pihak Dinas Perhubungan kembali memeriksa keadaan kendaraan dan sampai proses buku uji berkala dikeluarkan oleh Dinas Perhubungan. ${ }^{11}$

Berdasarkan hasil wawancara dengan Pemilik PO. Bus di Kabupaten Kampar terkait dengan pelaksanaan uji berkala kendaraan bus menjelaskan bahwa dalam pelaksanaannya pengusaha kendaraan umum angkutan barang dengan operasional jarak dekat dengan rata-rata penghasilan sedikit, beranggapan bahwa pelaksanaan uji berkala kelayakan kendaraan sangat memberatkan bagi pemilik atau pelaku usaha jasa transportasi jarak dekat. Meskipun uji berkala itu wajib dan sudah mempunyai aturan tersendiri, namun bagi pemilik kendaraan yang keluaran lama ini tetap saja memberatkan, lagi pula pelaksanaan pemeriksaannyapun tidak begitu maksimal dan lambat kedanya. Beda dengan perusahaan otomotif yang berskala besar, pengusaha tersebut sudah mempunyai modal yang besar pula. Kalo, perusahaan besar mudah dalam menjalankan aturan tersebut karena pemasukan besar modal juga besar, apabila kendaraan kecil milik orang desa. (angkutan pedesaan) banyak yang mengeluh, ban dengan kampasnya saja pinjam untuk pelaksanaan pengujian berkala, yang penting suratnya keluar, kendaraan bisa jalan. Dalam masa perbaikan malah sering dilakukan dibengkel umum langsung agar tidak banyak uang keluar. Yang selama ini di ikuti aturan dari Dinas Perhubungan juga hanya memeriksa dan solusinya pemilik kendaraan juga tetap memperbaikinya dibengkel umum juga. ${ }^{12}$

Berdasarkan hasil wawancara dengan Ketua Yayasan Lembaga Konsumen Indonesia Provinsi Riau menjelaskan keterkaitan dalam keselamatan angkutan kendaraan bus yang membawa penumpang memang sudah seharusnya diperiksa rutin dalam ketentuan hukumnya. Jika pemeriksaan kendaraan itu mengharuskan pemeriksaan berkalanya pada Dinas Perhubungan, pemilik bus harus mematuhi aturan tersebut karena ini sudah aturannya. Jika dikatakan tibet, remit, lama atau memakan waktu itu semua sudah prosedurnya begitu, ketika pengusaha kendaraan bus tidak mengikuti aturan artinya sudah bertentangan dengan hukum,

\footnotetext{
${ }^{11}$ Hasil wawancam dengan Bapak H. Yasri selaku Pemilik PO. Bus Silvana di Kabupaten Kampar, pada tanggal 17 November 2018, Jam 15.20 Wib di Bangkinang-Kabupaten Kampar.

${ }^{12}$ Hasil wawancara dengan Bapak H. Nurhadi selaku Pemilik PO. Bus N. Hadi di Kabupaten Kampar, pada tanggal 16 November 2018, Jam 16.00 Wib di Bangkinang-Kabupaten Kampar.
} 
ketika dilanggar pihak pengusaha angkutan bus tentu sudah dapat memahami segala konsekuensi karena pelanggaran tersebut. Tujuan Dinas Perhubungan tentu sangat baik untuk melmdungi masyarakatnya, sehingga dalam perjalanan waktu pemilik/pengusaha kendaraan bus dapat memberikan pelayanan terbaiknya kepada pengguna jasa angkutannya. ${ }^{13}$

Dinas Perhubungan dalam hal ini dapat melakukan pemeriksaan sewaktu-waktu oleh petugas dengan tujuan untuk keselamatan, keamanan, dan ketertiban lalu lintas dan angkutan jalan. Pada dasarnya, pelaksanaan uji kendaraan bermotor dilakukan untuk memastikan betel kondisi fisik kendaraan bermotor yang diujikan. Apakah ada jaminan layak jalan atau tidak. Sehingga target Dinas Perhubungan untuk selalu mengutamakan sisi keselamatan pengguna kendaraan bermotor, bisa tercapai. Kendaraan bermotor berpotensi mencelakai orang kalau kondisinya tidak diperhatikan series. Karen itu, sudah seharusnya pemilik kendaraan bermotor punya kesadaran tinggi untuk merawat sekaligus memeriksakannya melalui uji kendaraan bermotor.

Berdasarkan hasil observasi dilapangan ditemukan bahwa dalam pelaksanaan kewajiban uji berkala kendaraan bus menjadi hal yang berat dilakukan oleh pengusaha angkutan bus. Hal ini dikarenakan dengan syarat lulus uji kelayakan kendaraan bermotor yang mengharuskan komponen kendaraan dalam kondisi prima, yang berarti perawatan kendaraan menjadi indikator kelulusan uji kelayakan kendaraan bermotor. Biaya operasional kendaraan bermotor termasuk komponen dan suku cadang yang mahal harganya, serta semakin bertambahnya kendaraan bermotor pribadi, membuat pemasukan pelaku usaha jasa angkutan umum berkurang. Kesiapan dan kesadaran pars pelaku usaha transportasi yang menggunakan kendaraan besar dalam menjalankan usahanya untuk mentaati peraturan pelaksanaan uji kelayakan kendaraan bemotor adalah penting. Oleh karena itu dalam sebuah perusahaan transportasi dituntut mampu memberikan perawatan kepada setiap armada yang ber alan. Faktor non teknis secara umum disebabkan karena human error yang biasa terjadi pada brainware yang mengoperasikan kendaraan tersebut atau pada kendaraan lain sehingga menyebabkan terjadinya suatu gangguan kecelakaan.

\footnotetext{
${ }^{13}$ Hasil wawancara dengan Bapak Sukardi Ali Azhar selaku Ketua Yayasan Lembaga Konsumen Indonesia Provinsi Riau, pada tanggal 17 November 2018, Jam 17.00 Wib di Jl. Hang Tuah No. 153 Kota Pekanbaru.
} 


\section{Hambatan Pelaksanaan Kewajiban Uji Berkala Kendaraan Bus Berdasarkan Undang- Undang Nomor 22 Tahun 2009 Tentang Lalu Lintas dan Angkutan Man di Dinas Perhubungan Kabupaten Kampar}

Berdasarkan pelaksanaan kewajiban uji berkala kendaraan bus, pengawasan pengujian dalam hubungannya dengan keselamatan penumpang dapat dilakukan pemeriksaan sewaktu-waktu oleh petugas dengan tujuan untuk keselamatan, keamanan, dan ketertiban lalu lintas dan angkutan jalan. Konsep merupakan konsep yang baik untuk mengurangi resiko kecelakaan dan pencemaran udara akibat beroperasinya kendaraan bermotor. Hal tersebut sejalan dengan amanat Undang-Undang Nomor 22 Tahun 2009 tentang Lalu Lintas dan Angkutan Jalan yang tertera. pada Pasal 53 menyebutkan bahwa pengujian berkala diwajibkan untuk mobil penumpang, umum, mobil bus, mobil barang, kereta gandengan, dan kereta tempelan yang dioperasikan di jalan. Namun hal ini belum sepenuhnya dapat diterapkan karena masih terdapat hambatan-hambatan dilapangan.

Berikut merupakan faktor penyebab pengemudi atau pemilik kendaraan bus tidak melakukan pengujian berkala yang disebabkan oleh beberapa faktor:

\section{Faktor Geografis}

Faktor geografis yang menjadi penghambat dalam pelaksanaan kewajiban pengujian berkala kendaraan bus adalah karena luasnya wilayah kerja Dinas perhubungan Kabupaten Kampar. Luasnya wilayah Kabupaten Kampar tidak didukung oleh pembangunan Unit Pelayanan Teknis untuk melakukan uji berkala di daerah-daerah sehingga sangat menyulitkan bagi pemilik PO yang ada didaerah untuk melakukan uji berkala karena jauhnya jarak tempuh yang harus dijalani.

\section{Faktor Ekonomi}

Pengaruh faktor ekonomi yang mendasar dalam mempengaruhi Pemilik PO terhadap pelaksanaan kewajiban pengujian berkala terhadap kendaraan bus adalah Pemilik PO selalu berpikiran mengejar target agar omset pendapatan setiap bulan tercapai. Pemilik PO selalu menilai bahwa melakukan uji berkala akan memakan waktu lama dan dianggap merugikan pendapatan, sehingga Pemilik PO selalu menekankan kepada pengemudinya untuk mencari penumpang sebanyak mungkin, guna tercapainya omset yang ditargetkan pemilik PO sehingga kebijakannya dapat melalaikan atau mengabaikan perawatan kendaraan yang dapat mengancam keselamatan jiwa pengemudi ataupun penumpang didalamnya. Lamanya prosedur pemeriksaan uji berkala dan banyaknya pengemudi kendaraan yang mengantri untuk 
uji berkala membuat pemilik bus banyak kehilangan waktu untuk mengejar target pendapatan. Dalam pelaksanaan uji berkala belum tentu semuanya dapat berjalan lancar, jika kendaraan bus yang di uji ternyata tidak lulus uji maka pemilik bus harus memperbaikinya dibengkel umum sesuai dengan rekomendasi atau anjuran-anjuran yang tela ditetapkan dari tenaga penguji pihak Unit Pelaksana Teknis Pengujian Kendaraan Bermotor Kabupaten Kampar dan kemudian kendaraan yang tadinya tertunda harus kembali lagi ke Unit Pelaksana Teknis Pengujian Kendaraan Bermotor untuk melakukan pemeriksaan ulang.Berikut merupakan contoh gambar kendaraan bus yang tidak lulus uji setelah dilakukan uji berkala sebagai berikut:

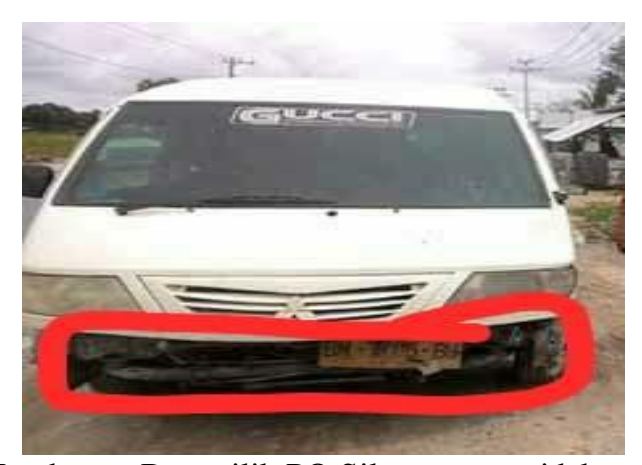

Keterangan: Kendaraan Bus milik PO Silvana yang tidak memenuhi syarat laik jalan dan tidak lulus uji berkala karena Bumper Depan Kendaraan tidak ada.

\section{Kesadaran Pemilik}

Rendahnya tingkat kesadaran pemilik PO dalam melakukan kewajiban uji berkala terhadap kendaraan bus merupakan penyebab utama pemilik PO. Pemilik PO lebih mengutamakan dan mempercayakan bengkel umum daripada melakukan pemeriksaan uji berkala yang diselenggarakan oleh Dinas Perhubungan. Pemilik PO belum menyadari pentingnya keselamatan jiwa untuk orang banyak. Dalam prosedurnya pemeriksaan uji berkala itukan meliputi uji teknis dan uji laik jalan. ketika kedua dasar komponen tersebut telah teruji dinas perhubungan akan mengeluarkan hasil lulus uji. Tetapi jika perbaikan tersebut hanya dilakukan pada bengkel umum yang akan dilakukan adalah memperbaiki kendaraan atas dasar perbaikan yang dirasakan adanya ketidaknyamanan atau tidak berfungsinya suatu bagian komponen kendaraan saja. Proses pengujian kelaikan kendaraan bermotor yang tidak sebentar menyebabkan pengemudi/pemilik kendaraan kendaraan bus tidak mau melakukan pelaksanaan uji berkala. 
Berdasarkan hasil pembahasan diatas dapat di simpulkan bahwa yang menjadi hambatan pelaksanaan kewajiban uji berkala kendaraan bus berdasarkan UndangUndang Nomor 22 Tahun 2009 tentang Lalu Lintas dan Angkutan Jalan di Kabupaten Kampar adalah ketidaklengkapan alat uji bahkan di beberapa unit pengujian masih menggunakan uji visual atau feeling penguji, Unit Pelaksana Teknis Pengujian Kendaraan Bermotor yang belum terakreditasi mencakup kelembagaan, infrastruktur, kurikulum, kendaraan, pelatihan, dan sarana lainnya. Faktor lain yang mempengaruhi kinerjanya adalah faktor internal seperti sumber daya manusia dan faktor ekternal seperti sarana dan prasarana kedinasan seperti faktor ekonomi dan faktor sosial. Selain itu mengenai Prosedur Operasi Standar dalam perusahaan jasa transportasi umum yang dinyatakan oleh Kementerian Perhubungan selayaknya diterapkan dan diimplementasikan oleh perusahaan otobus.

\section{Upaya Mengatasi Hambatan Pelaksanaan Kewajiban Uji Berkala Kendaraan Bus Berdasarkan Undang-Undang Nomor 22 Tahun 2009 Tentang Lalu Lintas dan Angkutan Jalan di Dinas Perhubungan Kabupaten Kampar}

Permasalahan transportasi publik di Indonesia masih menjadi permasalahan klasik diseluruh daerah. Kecelakaan lalu lintas, pembagian jalur dan ketertiban penyelenggara transportasi menjadi penyumbang masalah terbesar dalam permasalahan transportasi. Selain itu fenomena pertumbuhan jumlah ruas jalan yang tidak seimbang dengan perkembangan jumlah kendaraan bermotor mampu menyebabkan permasalahan tersendiri bagi pemerintah. Permasalahan akut ini sepertinya sudah menjadi selayaknya tanggungjawab pemerintah untuk menyelesaikan pekerjaan rumahnya yang tidak kunjung selesai.

Dinas Perhubungan Kabupaten Kampar merupakan salah satu instansi pemerintahan yang diberikan wewenang dan tanggung jawab dalam hal pengujian berkala. Dengan demikian terlihat jelas bahwa Dinas Perhubungan Kabupaten Kampar merupakan sebuah instansi vertikal dibawah Pemerintahan Kabupaten Kampar. Berkaitan dengan pertanggungjawaban Dinas Perhubungan Kabupaten Kampar dalam melakukan pemeriksaan kendaraan bus kepada masyarakat atau pemilik kendaraan, maka semua pihak harus memberikan kinerja kepada masyarakat dengan penuh ketelitian, profesionalisme pegawai, dan kedisiplinan.

Kebijakan dan peraturan perundang-undangan dalam bidang pengujian berkala sangat diperlukan agar masing-masing pegawai mampu melaksanakan tugas dan wewenang 
dengan sebaik-baiknya. Hal tersebut perlu ditekankan mengingat tugas besar yang diberikan kepada Dinas Perhubungan Kabupaten Kampar sebagai satu satunya instansi pemberi layanan dalam bidang pengujian berkala di Kabupaten Kampar. Untuk itulah diperlukan adanya laporan pertanggungjawaban.

Laporan pertanggungjawaban di Dinas Perhubungan Kabupaten Kampar dilaksanakan secara berkala. Melakukan perencanaan kegiatan dalam rangka meminimalisir pelanggaran pengujian berkala pada angkutan umum khususnya Angkutan penumpang. Dalam hal ini Dinas Perhubungan Kabupaten Kampar dalam rangka meminimalkan pelanggaran terhadap pemeriksaan pengujian berkala akan melakukan berbagai upaya untuk memaksimalkan pelayanan dibidang transportasi.

\section{Faktor Geografis}

Untuk mengatasi hambatan karena faktor luasnya wilayah Kabupaten Kampar tidak didukung oleh pembangunan Unit Pelayanan Teknis untuk melakukan uji berkala di daerahdaerah maka Dinas Perhubungan Kabupaten Kampar mempunyai wacana untuk membangun Unit Pelayanan Teknis uji berkala di beberapa kecamatan yang memiliki potensi guna memudahkan bagi pengguna fasilitas uji berkala untuk memeriksakan keadaan kendaraannya. Namun ini harus mendapatkan persetujuan dari Bupati Kabupaten Kampar dan DPRD Kabupaten Kampar, karena ini sangat berhubungan dengan alokasi anggaran dan evaluasi dari Bupati untuk menganalisa prasarana dan sarananya.

\section{Faktor Ekonomi}

Untuk mengatasi hambatan tersebut pihak Dinas Perhubungan akan melakukan investigasi langsung kesetiap PO guna meminimalisir terjadinya kecelakaan akan memberikan sanksi berupa pemutusan izin trayek sampai pada pembekuan izin usaha bagi pemilik PO yang tidak melakukan kewajiban uji berkala. Jika sanksi telah dijatuhkan kepada pemilik PO tentu saja sopir atau pemilik PO Nya juga tidak dapat menjalan usahanya. Namun ternyata kendaraan bus yang tanpa izin trayek masih melaksanakan operasinya maka Dinas perhubungan akan menggalakkan sosialisasi juga akan melakukan razia rutin terhadap kelaikan kendaraan. Kemudian melakukan perbaikan alat alat yang rusak dan mengganti peralatan atau komponen barang yang tidak bisa dipakai dengan yang baru untuk memperlancar kinerja uji berkala. 


\section{Kesadaran Pemilik}

Upaya mengatasi rendahnya tingkat kesadaran pemilik PO dalam melakukan kewajiban uji berkala terhadap kendaraan bus maka pihak Dinas Perhubungan akan melakukan pembinaan dan sosialisasi terhadap pentingnya keselamatan jiwa pengemudi ataupun penumpangnya dan juga meningkat pengawasan terhadap pemilik PO yang tingkat kesadarannya rendah dalam melakukan pemeriksaan kendaraan bus dijalan terhadap tanda bukti lulus uji laik jalan dan uji fisik kendaraan. Karena untuk melakukan pemeriksaan lulus uji laik jalan dan uji fisik membutuhkan tenaga ahli dan alat khusus yang tidak akan ditemukan dibengkel umum lainnya

Upaya mengatasi hambatan dalam pelaksanaan kewajiban uji berkala kendaraan bus berdasarkan Undang-Undang Nomor 22 Tahun 2009 tentang Lalu Lintas dan Angkutan Jalan di Kabupaten Kampar adalah melakukan kegiatan operasi atau razia terhadap angkutan penumpang dengan tujuan untuk meminimalkan terjadinya pelanggaran dalam pengujian berkala. Untuk meningkatkan kesadaran uji kendaraan yang masyarakat masih rendah, Dishub akin membangun sistem untuk pengadaan sistem pengujian berkala elektronik. Selain itu, menggalakkan sosialisasi juga akan melakukan razia rutin terhadap kelaikan kendaraan. Hal lain yang dianggap perlu menambah jumlah personil/pegawai fungsional di UPTD, meningkatkan akuntabilitas digunakan sebagai indikator yang menunjukkan kesesuaian antara kegiatan pengujian berkala. Serta melakukan pemeriksaan terhadap bagian-bagian yang ada dikendaraan diperlukan seorang teipaga yang mempunyai kemampuan atau keahlian khusus yang mengetahui seluk beluk tentang pengujian. Agar pelaksanaaan kegiatan pengujian sesuai dengan yang diharapkan dan akurat, diperlukan petugas penguji atau tenaga ahli yang berpengalaman. Demi kelayakan jalan pada setiap kendaraan bus umum akan dilakukan inspeksi rutin oleh pejabat dinas terkait dalam hal ini Dinas Perhubungan, dengan tujuan menekan angka kerusakan, kecelakaan, serta memberikan kenyamanan bagi pengguna jalan maupun pengguna transportasi.

\section{KESIMPULAN}

Pelaksanaan kewajiban uji berkala kendaraan bus berdasarkan Undang-Undang Nomor 22 Tahun 2009 tentang Lalu Lintas dan Angkutan Jalan di Kabupaten Kampar belum dapat terlaksana sebagaimana mestinya, karena hal ini masih banyak ditemukan kendaraan 
bus umum yang tidak melakukan uji persyaratan laik jalan di Dinas Perhubungan kabupaten Kampar. Pelaksanaan pengujian kendaraan bermotor yang seharusnya wajib dilakukan secara berkala tetapi tidak berjalan dengan efektif, karena masih banyak kurangnya kesadaran dari pemilik bus umum untuk tertib terhadap aturan mengenai pengujian syarat laik jalan. Hambatan pelaksanaan kewajiban uji berkala kendaraan bus berdasarkan Undang-Undang Nomor 22 Tahun 2009 tentang Lalu. Lintas dan Angkutan Jalan di Kabupaten Kampar karena terhambat oleh beberapa faktor seperti faktor geografis, faktor ekonomi, dan faktor kesadaran pemilik. Upaya mengatasi hambatan dalam pelaksanaan kewajiban uji berkala kendaraan bus dengan membangun Unit Pelayanan Teknis uji berkala di beberapa kecamatan yang memiliki potensi guna memudahkan pengguna fasilitas uji berkala untuk memeriksakan keadaan kendaraannya. Memberikan sanksi pemutusan izin trayek dan pembekuan izin usaha bagi pemilik PO yang tidak melakukan kewajiban uji berkala.

\section{DAFTAR PUSTAKA}

Adisasmita, S A. Dasar-dasar Ekonomi Transportasi, Yogyakarta: Graha Ilmu, 2010.

Adisasmita, S A. Transportasi dan Pengembangan Wilayahnya, Yogyakarta: Graha Ilmu, 2011 .

Salim, A. Manajemen Transportasi. Jakarta : PT. Raja Grafindo Persada, 1993.

Soegijatna Tjakranegara, Hukum Pengangkutan Barang dan Penumpang, Jakarta: Rineka Cipta, 2007

Thomas Subroto, Tanya Jawab Undang-Undang Lalu Lintas dan Angkutan, Semarang: Dahara Prize, 2008

\section{Web}

mengenal-aturan-uji-kir-kendaraan-umum-dasar-hukum-hingga-sanksi, diakses hari Jumat, Tanggal 14 Desember 2018, http://www.tribunnews.com/otomotif/2016/06/18/ 